\title{
Pola Komunikasi Dakwah Majelis Ta'lim Salafi Studi Kasus: Desa Talang Tinggi Bengkulu Selatan
}

\author{
Daryanto \\ Magister Komunikasi dan Penyiaran Islam \\ Fakultas Dakwah dan Komunikasi Universitas Islam Negeri Sunan \\ Kalijaga Yogyakarta \\ email: ddaryanto661@gmail.com
}

\begin{abstract}
Majelis ta'lim is present in Indonesia as a non-formal educational institution that aims to provide an understanding of Islam to people who are hungry for spiritual cleansing. One of them is the Salafi Ta'lim Assembly located in the village of Tanjung Tinggi, South Bengkulu. With the communication approach, it is seen that the communication patterns in the Salafi majelis use interpersonal communication patterns and group communication, but the pattern of group communication tends to be preferred.
\end{abstract}

Keywords: Communication Pattern, Taklim Assembly, Salafi

\begin{abstract}
Abstrak
Majelis ta'lim hadir di Indonesia sebagai lembaga pendidikan non formal yang bertujuan untuk memberikan pemahaman Islam kepada masyarakat yang haus akan siraman rohani. Salah satunya adalah Majelis Ta'lim Salafi yang terletak di Desa Tanjung Tinggi Bengkulu Selatan. Dengan pendekatan komunikasi, terlihat bahwa pola komunikasi di majelis ta'lim Salafi menggunakan pola komunikasi antarpribadi dan komunikasi kelompok, namun pola komunikasi kelompok cenderung lebih diutamakan.
\end{abstract}

Kata kunci: Pola Komunikasi, Majelis Taklim, Salafi 


\section{A. Pendahuluan}

Indonesia merupakan negara dengan penduduk mayoritas Islam. Dengan demikian tidak diragukan lagi apabila setiap umat Islam harus memperoleh pembinaan keagamaan supaya dalam kehidupannya tidak terlepas dari nilai-nilai Islam. Sebab, dengan memahami banyak syari'at agama Islam, maka mereka akan dapat menjadi manusia yang memiliki tujuan dalam hidupnya serta memperoleh kebahagiaan duniawi dan juga ukhrawi sebagai tujuan hidup.

Ilmu-ilmu agama Islam yang disampaikan melalui pembinaan keagamaan pada setiap muslim tersebut merupakan salah satu bentuk usaha dalam menjadi seorang muslim sejati sebagaimana yang diperintahkan oleh Rasulullah SAW, bahwa sebelum beramal hendaklah berilmu terlebih dahulu. Maka dalam konteks ini bentuk pembinaan tersebut tidaklah mesti bersifat formal melainkan juga dapat dilakukan dengan sifatnya informal seperti pengajian ataupun majelis ta'lim.

Majelis ta'lim merupakan lembaga pendidikan non formal Islam yang memiliki kurikulum tersendiri, diselenggarakan secara berkala dan teratur,diikuti oleh beberapa orang jama'ah serta bertujuan untuk membina dan mengembangkan hubungan yang serasi antar sesama manusia maupun manusia dengan Allah dan lingkungannya (Nurul Huda, 2010: 5).

Disisi lain, majelis ta'limjuga sebagai wahana atau sarana untuk mentransfer nilai-nilai agama.Maka tidak heran jika kegiatan majelis ta'limdikenal sebagai proses pendidikan yang mengarah pada internalisasi nilai-nilai agama. Artinya, jamaah majelis ta'limdiharapkan mampu merefleksikan tatanan normatif dalam realitas kehidupan sehari-hari. Sehingga secara strategis, majelis ta'limmenjadi sarana dakwah dan tabligh yang berperan sentral pada pembinaan dan peningkatan kualitas hidup umat Islam.

Disamping itu,majelis ta 'lim juga berguna untuk menyadarkan umat Islam agar menghayati dan mengamalkan ajaran agamanya yang 
kontekstual kepada lingkungan hidup sosial budaya dan alam sekitar. Sehingga dapat menjadikan umat Islam sebagai Ummatan Washatanyang menjadi teladan kelompok umat lain (H.M Arifin, 2005:120).

Keberadaan majelis ta'lim dalam masyarakat Indonesia dapat dikatakan sebagai fenomena yang unik. Karena selain merupakan produk dan hasil dari kebudayaan dan peradaban yang telah dicapai oleh umat Islam di abad20 ini, lembaga ini juga pernah dilakukan oleh Rasulullah SAW dahulu. Bahkan, majelis ta'lim telah memberikan arti tersendiri dalam dakwah dan pengembangan Islam serta menjadi salah satu bentuk serta cara dalam melakukan sosialisasi ajaran Islam.

Begitupun juga yang terjadi di masyarakat Desa Talang Tinggi, Kabupaten Seluma, Bengkulu,yang masih sangat membutuhkan pendidikan dasar agama untuk membenahi diri,keluarga dan masyarakat. Meskipun ada keluarga yang mempunyai dasar agama, namun masih sulit untuk melakukan ibadah. Pengaruh lingkungan yang serba mementingkan materi, menyebabkan umat Islam mempunyai kendala untuk melakukan ibadah yang sesuai dengan tuntunan.

Dalam kondisi yang demikian, masyarakat perlumendapat upaya pembenahan penerapan nilai-nilai agama Islam dalamkehidupan. Hal itu dikarenakan untuk menguatkan kembali nilai agama yang telah ada pada setiapmanusia, diperlukan tindakan untuk membekali masyarakat dalam mewujudkanakhlakulkarimahseperti diadakan pengajian rutin ataumajelista'lim.Sehinggadiharapkan masyarakat mampu memikul amanah dalam menguatkan nilai agamadan mencetak generasi Islami dalam keluarga dan masyarakat.

Berangkat dari masalah keagamaan dan harapan masyarakat Desa Talang Tinggi, Kabupaten Seluma, Bengkulu, maka terbentuklah sebuah wadah pendidikan non formal bernama Majelis Ta'lim Salafi bagi masyarakat untuk memenuhi hasrat rohani. Warga yang mengikutimajelis tersebut tidak hanyayang berdomisili di Desa Talang Tinggi Kabupaten 
Seluma, namun banyak pula warga yang berdatangan berasal daritetangga desa.

Namun, keberadaan majelis ta'limsalafi tidak serta merta langsung diterima oleh seluruh lapisan masyarakat. Hal ini dikarenakan masyarakat menganggap bahwa para anggota majelis ta'lim ini memiliki sifat eksklusif dengan menentang budaya nenek moyang. Seringkali masyarakat menganggap bahwa ajaran yang disampaikan dalam ta'lim Salafi adalah sesat karena melarang masyarakat untuk melakukan kegiatan-kegiatan (yang dianggap ibadah) oleh masyarakat Desa Talang Tinggi Kabupaten Seluma.

Berdasarkan latar belakang permasalahan, peneliti akan mengkaji penelitian dengan ilmu komunikasi. Maka dalam hal ini, melalui komunikasi akan terlihat bagaimana pola komunikasi yang digunakan dalam perjalanan majlis ta'lim salafi sebagai subyek yang berperan penting dalam dakwah yang dimaksud. Pada penelitian ini penulis mengajukan judul penelitian "Pola Komunikasi Dakwah Majelis Ta'lim Salafi Studi Kasus: Desa Talang Tinggi Bengkulu Selatan”

\section{B. Metode Penelitian}

Dalam hal ini, menarik untuk dikaji lebih dalam yaitu mengenai pola komunikasi yang kemudian dibangun oleh pengurus ataupun ustadz yang mengisi majlis ta'lim salafi dalam memberikan penjelasan kepada jamaahnya yang berasal dari masyarakat Desa Talang Tinggi Kabupaten Seluma, Bengkulu. Dengan informan dalam penelitian ini yaitu jamaah majelis ta'lim Salafi, masyarakat, tokoh masyarakat dan perangkat Desa Talang Tinggi Kabupaten Seluma, serta dengan teknik pengumpulan data observasi, wawancara dan dokumentasi.

\section{Pembahasan}


Penelitian ini akan membahas bagaimana pola komunikasi yang dilakukan Ustad Salaf dalam sarana komunikasi yaitu majlis ta'lim. Sehingga dengan adanya komunikasi oleh Ustad yang tergabung dalam jama'ah majlis ta'lim salafi kepada masyarakat, diharapkan akan memberikan penjelaasan yang baik sampai benar-benar memahami apa tujuan ta'lim. Maka, dalam hal ini pola komunikasi yang ditekankan adalah komunikasi antarpribadi dan komunikasi kelompok.

\section{C.1 Komunikasi}

Komunikasi berasal dari bahasa latin,communicare yang berarti menyebarluaskan atau memberitahukan. Dari kata communicare tersebut, kemudian diterjemahkan dengan kata communis atau communal yang mengandung arti milik bersama atau kebersamaan atau secara umum dapat dikatakan sebagai berlaku umum sifatnya. Dalam Kamus Besar Bahasa Indonesia,komunikasi adalah pengiriman dan penerimaan pesan atau berita antara dua orang atau lebih dengan cara yang tepat sehingga pesan yang dimaksud dapat dipahami (Chulsum dan Novia, 2006: 388).Komunikasi juga berarti proses penyampaian suatu pernyataan oleh seseorang kepada orang lain, baik yang melibatkan sejumlah orang atau seseorang saja.

Menurut bahasa (etimologi) dalam "Ensiklopedi Umum" diartikan dengan "perhubungan", sedangkan yang terdapat dalam buku komunikasi berasal dari perkataan latin (Roudhonah, 2007:21), yaitu: 1) Communicare, yang berarti berpartisipasi ataupun memberitahukan, 2) Communis, yang berarti milik bersama ataupun berlaku dimana-mana, 3) Communis opinion, yang berarti pendapat umum atau pendapat mayoritas, 4) Communico, yang berarti membuat sama, 4) Demikian juga Communication berasal dari kata latin communicatio yang juga bersumber dari kata Communis yang berarti sama. Sama disini maksudnya sama makna.

Menurut Edward Depari, komunikasi adalah proses penyampaian gagasan, harapan, dan pesan yang disampaikan melalui lambang tertentu, 
mengandung arti, dilakukan oleh penyampai pesan ditujukan kepada penerima pesan.Sejalan dengan Theodore Herbert,komunikasi ialah proses yang didalmnya menunjukan arti pengetahuan dipindahkan dari seorang kepada orang lain, biasanya dengan maksud mencapai beberapa tujuan khusus (Mulyana, 2005:53).

Ada beberapa jenis pola komunikasi yaitu; a) komunikasi intrapersonal, b) komunikasi antar pribadi, c) komunikasi kelompok, d) komunikasi massa (Mulayana, 2005: 57).

1. Komunikasi intrapersonal

Komunikasi intrapersonal adalah penggunaan bahasa atau pikiran yang terjadi di dalam diri komunikator sendiri. Komunikasi intrapersonal merupakan keterlibatan internal secara aktif dari individu dalam pemrosesan simbolik dari pesan-pesan. Seorang individu menjadi pengirim sekaligus penerima pesan, memberikan umpan balik bagi dirinya sendiri dalam proses internal yang berkelanjutan.

Contoh dari proses komunikasi intrapersonal ini misalnya, ketika seseorang memutuskan untuk berdo'a, mengkhayal, bahkan bertapa untuk lebih memahami apa yang diinginkan dirinya atau bahkan untuk mengambil keputusan.

2. Komunikasi antar pribadi

Komunikasi antarpribadi merupakan pengiriman pesan-pesan dari seorang dan diterima oleh orang yang lainatau sekelompok orang dengan efek dan umpan balik yang langsung. Pada hakikatnya komunikasi antar pribadi adalah komunikasi antara komunikator dengan seorang komunikan. Komunikasi jenis ini dianggap paling efektif dalam hal upaya mengubah sikap, pendapat, atau perilaku seseorang, karena sifatnya yang dialogis, berupa percakapan. Arus balik bersifat langsung. Komunikator mengetahui tanggapan komunikan ketika itu juga pada saat komunikasi dilancarkan. Komunikator mengetahui pasti apakah komunikasinya itu positif atau negatif, berhasil atau tidak. Jika tidak, ia dapat memberi kesempatan kepada komunikan untuk bertanya seluas-luasnya. 


\section{Komunikasi kelompok}

Komunikasi kelompok sebagai interaksi secara tatap muka antara tiga orang atau lebih, dengan tujuan yang telah diketahui, seperti berbagi informasi, menjaga diri, pemecahan masalah, yang mana anggotaanggotanya dapat mengingat karakteristik pribadi anggota-anggota yang lain secara tepat. Kelompok adalah sekumpulan orang yang mempunyai tujuan bersama yang berinteraksi satu sama lain untuk mencapai tujuan bersama, mengenal satu sama lainnya, dan memandang mereka sebagai bagian dari kelompok tersebut (Mulayana, 2005:57). Kelompok ini misalnya adalah keluarga, kelompok diskusi, kelompok pemecahan masalah, atau suatu komite yang tengah berapat untuk mengambil suatu keputusan. Dalam komunikasi kelompok, juga melibatkan komunikasi antarpribadi. Karena itu kebanyakan teori komunikasi antarpribadi berlaku juga bagi komunikasi kelompok.

4. Komunikasi massa

Komunikasi massa adalah komunikasi yang ditujukan kepada massa, kepada khalayak yang luar biasa banyaknya. Ini tidak berarti bahwa khalayak meliputi seluruh penduduk atau semua orang yang membaca atau semua orang yang menonton televisi. Komunikasi massa adalah komunikasi yang disalurkan oleh pemancar-pemancar yang audio dan atau visual. Komunikasi massa barangkali akan lebih mudah dan lebih logis bila didefenisikan menurut bentuknya:televisi, radio, surat kabar, majalah, film, buku dan pita (Nurudi, 2012 26:46).

Bentuk-bentuk interaksi dalam proses komunikasi dapat berupa kerjasama, persaingan, bahkan dapat juga berbentuk pertentangan atau pertikaian.Di bawah ini akan dijelaskan bentuk-bentuk interaksi, yaitu

a. Kerjasama (Cooperation)

Kerjasama timbul karena orientasi orang perorangan terhadap kelompok lain. Kerjasama mungkin akan bertambah kuat apabila ada bahaya dari luar yang mengancam atau ada tindakan-tindakan dari luar yang mengancam atau ada tindakan-tindakan dari luar yang menyinggung 
kesetiaan yang secara tradisional atau institusional telah tertanam di dalam kelompok(Sarlito, 2000:80).

b. Persaingan (Competion)

Persaingan dalam batas-batas tertentu mempunyai beberapa fungsi, yaitu: 1)Menyalurkan keinginan-keinginan individu atau kelompok yangbersifat kompetitif. 2) Sebagai jalan yang menyebabkan keinginan, kepentingan serta nilai-nilai yang pada suatu masa menjadi pusat perhatian, tersalurkan dengan baik oleh masyarakat yang bersaing. 3)Merupakan alat untuk mengadakan seleksi atas dasar seks dan sosial.

4) Alat untuk menyaring para warga golongan karya (fungsional) yang akhirnya akan menghasilkan pembagian kerja yang efektif.

c. Pertentangan (pertikaian atau konflik)

Pertentangan merupakan suatu proses sosial dimana individu atau kelompok berusaha memenuhi tujuannya dengan jalan menentang pihak lawan yang disertai dengan ancaman dan kekerasan.

Pertentangan mempunyai beberapa bentuk khusus, antara lain: pertentangan pribadi, pertentangan rasial, pertentangan antara kelaskelas sosial, pertentangan politik, dan pertentangan yang bersifat internasional.

d. Akomodasi

Tujuan akomodasi dapat berbeda-beda sesuai dengan situasi yang dihadapinya, yaitu: 1) Mencegah terjadinya suatu pertentangan untuk sementara waktu. 2) Untuk memungkinkan terjadinya kerjasama antara kelompok-kelompok sosial yang hidupnya terpisah sebagai faktor sosial, psikologis dan kebudayaan. 3) Mengusahakan peleburan antara kelompok-kelompok sosial yang terpisah.

\section{C.2 Pola Komunikasi Majelis Ta'lim Salafi}

Pada bagian ini, penulis akan menyajikan hasil penelitian yang telah penulis dapatkan dari lapangan yang berkaitan dengan pola 
komunikasi dakwah majelis ta'lim Salafi dalam meningkatkan ibadah masyarakat di Desa Talang Tinggi Kabupaten Seluma sebagai berikut.

\section{Komunikasi Antar Pribadi}

Komunikasi antarpribadi dalam majelis ta'limSalafi di Desa Talang Tinggi Kabupaten Selumaterlihat dari komunikasi antara ustadz dengan jamaah dalam kegiatan pembinaan ibadah yang dilakukan di luar Majelis Ta'lim. Hal itu terlihat dari jamaah yang datang sendiri setelah ditutup doa untuk menanyakan perihal pembinaan ibadah, atau masalah-masalah yang berkaitan dengan agama dan yang lainnya. Dalam hal ini majelis ta'lim menjalankan fungsinya sebagai pusat pembinaan dan pengembangan kemampuan dan kualitas sumber daya manusia dalam berbagai bidang seperti dakwah, pendidikan, sosial dan politik yang sesuai dengan kodratnya.Hal itu juga seperti yang disampaikan salahsatu jamaah bernama Sutris.

"Biasanya kalau mereka ingin melakukan pendalaman biasanya mereka dengan sendiri sendiri akan ngaji ke tempat ustadz menambah semacam, jadi secara pribadi yang ingin mendalami agama diberi kesempatan waktu untuk belajar juga di luar majelis taklim".

Berdasarkan hasil wawancara di atas dapat diketahui bahwa komunikasi pribadi antara ustadz dengan jamaah dilakukan di luar waktu taklim, artinya komunikasi pribadi dilakukan secara perseorangan antara jamaah dengan ustad pada saat ta'lim telah selesai atau dengan mendatangi ustadz di rumahnya dan menanyakan materi ta'lim yang belum dipahami.

Selain itu juga, komunikasi pribadi dilakukan untuk membina ibadah para jamaah dengan bertanya sendiri kepada ustdadz mengenai masalah-masalah agama. Hal itu seperti dijelaskan oleh jamaah bernama Muron Fitri. 
"Pernah, tapi tidak terus menerus paling saya ke rumah ustadz atau hadir di majelis ta'lim yang dipimpin ustadz di tempat lain, kan kalau di sini waktunya juga terbatas banget, paling selesai jam 11 malam jadi tidak bisa kalau untuk satu orang satu orang bertanya".

Berdsarkan hasil wawancara di atas dapat diketahui bahwa ustadz di majelis ta'lim Salafi juga menanggapi setiap masalah yang dihadapi oleh jamaahnya dan jamaah mendapatkan jawaban yang sangat luas dan ada timbal balik secara langsung sampai sangat jelas jawabannya. Penambahan dan pengembangan materi juga terjadi di majelis ta'lim ini karena melihat semakin majunya zaman dan semakin kompleks permasalahan yang perlu penanganan yang tepat. Hal itu dikarenakan majelis ta'limmerupakan salah satu struktur kegiatan dakwah yang berperan penting dalam mencerdaskan umat, maka selain pelaksanaannya harus sesuai teratur dan periodik juga harus mampu membawa jama'ah kearah yang lebih baik. Hal itu seperti disampaikan salahsat ustadz bernama Haji Apin.

"O iya pasti secara kelompok bentuknya satu arah kadang-kadang ada tanya jawab juga, tapi tidak setiap ustadz ceramah dan memang kalau ada pertanyaan tidak saya langsung jawab secara spontan itu dikarenakan untuk menghindari kesalahan jawaban".

Komunikasi antar pribadi juga terjadi diluar majelis ta'lim untuk menjaga hubungan antara ustadz dengan jamaahnya. Hal ini dilakukan pada saat ta'lim selesai atau ketika jamaah bersilaturahmi ke rumah Ustadz. Majelis ta'lim juga diharapkan menjadi jaringan komunikasi ukhuwah dan silaturahmi antar sesama, antara lain dalam membangun masyarakat dan tatanan kehidupan Islami (Muhsin, 2009: 7).Hal itu seperti dikatakanHaji Apin

"Kita tidak dekat hanya di majelis ta'lim saja, di luar majelis ta'lim juga antara saya dengan jamaah sangat dekat, semisal saya punya hajat saya undang ustadz dan jamaah lainnya begitu sebaliknya”. 
Berdasarkan hasil wawancara di atas dapat diketahui bahwa hubungan kekeluargaan antara ustadz dengan jamaah di majelis ta'lim salafi terjalin dengan erat artinya ketika ada hajat jamaah akan mengundang ustadz dan jamaah lain begitu sebaliknya.

Dari beberapa pernyataan jamaah majelis ta'lim diatas dapat disimpulkan bahwa komunikasi antarpribadi sebagai proses pengiriman pesan-pesan dari ustadz dan diterima oleh jamaah dengan efek dan umpan balik secara langsung. Sebagaimana dijelaskan oleh Dedy Mulyana bahwa pada hakikatnya komunikasi antar pribadi dianggap paling efektif dalam upaya mengubah sikap, pendapat, atau perilaku seseorang, karena sifatnya yang dialogis, berupa percakapan dan memiliki arus balik bersifat langsung.

Dengan menggunakan pola komunikasi antar pribadi, komunikator dalam hal ini ustadz, mengetahui tanggapan komunikan atau jamaah langsung pada saat komunikasi dilancarkan. Komunikator mengetahui pasti apakah komunikasinya itu positif atau negatif, berhasil atau tidak. Jika tidak, ia dapat memberi kesempatan kepada komunikan untuk bertanya seluas-luasnya (Mulyana, 2005:57).

Dengan demikian maka komunikasi antar pribadi antar ustadz dan jamaah dapat berjalan efektif bilamana terdapat komunikasi atau penyampaian pesan secara intens yang dilakukan antar personal yang dapat menambah pemahaman, merubah sikap, dan bertambah giat ibadah dalam kehidupan sehari hari.

\section{Komunikasi Kelompok}

Berdasarkan observasi lapangan,kegiatan ta'lim di majelis ta'lim Salafi, tidak hanya menggunakan komunikasi antarpribadi, tetapi juga mengguankan komunikasi kelompok. Hal itu terlihat dari kegiatan pembinaan ibadah yang dilakukan dengan membaca bersama-sama doa yang dipimpin oleh satu orang, begitu juga dengan ceramah agama yang disampaikan oleh seorang Ustadz.Hal ini juga diperkuat dari hasil wawancara dengan Kusnun seperti pada kutipan wawancara di bawah ini: 
"Komunikasi yang dipakai di majelis taklim ini yaitu secara kelompok, ustadz berceramah sedangkan jamaah mendengarkan, mencatat materi diterangkan selesai dari ceramah langsung ditutup doa, tidak ada Tanya jawab, kalau emang ada jamaah yang belum paham boleh bertanya setelah taklim selesai ini dengan maksud biar cepat selesai pengajiannya karena waktu juga kan terbatas. Mengenai materi yang disampaikan di antaranya fikih, tasawuf, akhlak, praktek sholat dan yang paling sering dibahas tentang boleh tidaknya kirim hadiah fatihah untuk keluarga yang sudah mati."

Penyataan diatas menjelaskan bahwa pola komunikasi kelompok menjadi sesuatu hal yang utama daripada komunikasi antar pribadi dalam majelis ini terutama dalam menyampaikan materi ceramah agama atau tausiah dari ustadz. Hal itu sejalan dengan konsep dakwah pada umumnya yang mempelajari seputar bagaimana memahami ajaran Islam baik untuk mengenal, memahami, menghayati, mengimani, bertaqwa berakhlak mulia, mengamalkan ajaran Islam dari sumber utamanya kitab suci Al-quran dan Al-Hadist melalui kegiatan bimbingan.

Maka secara garis besarnya, ada dua kelompok pelajaran dalam majelis ta'lim, yakni kelompok pengetahuan agama dan kelompok pengetahuan umum. Kelompok pengetahuan agama antara lain adalah Tauhid, Fiqh, Tafsir, Hadits, Akhlaq, Tarikh, dan Bahasa Arab. Sedangkan Kelompok pengetahuan umum bertema atau maudlu' yang disampaikan hendaknya hal-hal yang langsung ada kaitannya dengan kehidupan masyarakat. Kesemuanya itu dikaitkan dengan agama, artinya dalam menyampaikan uraian-uraian tersebut hendaklah jangan dilupakan dalildalil agama baik berupa ayat-ayat al-Qur'an atau hadits-hadits atau contohcontoh dari kehidupan Rasulullah SAW.Hal itu juga dikuatkan dengan pernyataan dari Kusnun, sebagaimana berikut.

"Ya ceramah agama pasti secara kelompok Ustadz ceramah dan didengarkan para jamaah. Di majelis taklim salafi ceramahnya satu arah, tidak ada tanya jawabnya kalau ada yang mau bertanya itu 
selesai taklim karena kalau ada tanya jawab waktunya terbatas jadi angsung di tutup doa. Kalau sudah selesai dari semuanya ada satu per satu jamaah bertanya.

Hal yang sama juga yang dikatakan olehSutris,

"Kalau di tempat ini kita kurang ya karena memang di sini waktunya sangat terbatas jadi sistemnya kelompok saja mengikuti bersama sama tapi kami juga membaca buletin dan juga ada bukunya untuk panduan kita dalami di rumah masing masing untuk dibaca bersama sama di majelis taklim".

Berdasarkan hasil wawancara di atas dapat diketahui bahwa cara ustadz dalam membina ibadah para jamaah adalah melalui nasehat secara kelompok. Adapun ceramah agama yang disampaikan oleh Ustadz di Majelis Ta'lim Salafi ini terjadi satu arah jika ada pertanyaan dari jamaah beliau tampung dahulu baru bulan depan akan dijawab. Seperti dari hasil wawancara bahwa beliau mengatakan,

"Biasanya kalau ada yang bertanya saya akan tampung dulu pertanyaannya baru bulan depan saya akan jawab, ini dikarenakan untuk menghindari kesalahan jawaban".

Jadi, pola komunikasi kelompok yang ada di Majelis Ta'lim Salafi menggunakan pola komunikasi kelompok satu arah di dalamnya. Tidak ada Tanya jawab setelah pembinaan ibadah. Tanya jawab tidak dilakukan di dalam kelompok jamaah majelis ta'lim, namun Tanya jawab antara ustazd dan jamaah berlangsung setelah selesai dari pengajian yang ada ditutup dengan doa.

Sebagaimana dijelaskan oleh Dedy Mulyana bahwa komunikasi kelompok sebagai interaksi secara tatap muka antara tiga orang atau lebih, dengan tujuan yang telah diketahui, seperti berbagi informasi, menjaga diri, pemecahan masalah, yang mana anggota-anggotanya dapat mengingat karakteristik pribadi anggota-anggota yang lain secara tepat. Kelompok adalah sekumpulan orang yang mempunyai tujuan bersama yang 
berinteraksi satu sama lain untuk mencapai tujuan bersama, mengenal satu sama lainnya, dan memandang mereka sebagai bagian dari kelompok tersebut (Mulyana, 2005:57).

\section{Penutup}

Dari hasil penelitian dapat disimpulkan bahwa pola komunikasi dakwah majelis ta'lim Salafi dalam meningkatkan ibadah masyarakat di Desa Talang Tinggi Kabupaten Seluma pertama, komunikasi antar pribadi yaitu dilaksanakan setelah ceramah agama (ta'lim) disampaikan oleh Ustadz dan ditutup dengan doa jamaah yang ingin bertanya tentang materi yang kurang paham dapat langsung menemui ustadz untuk bertanya mengenai materi dakwah seperti materi fikih, tasawuf, akhlak, praktek sholat. Kedua, komunikasi kelompok yaitu penyampaian pesan dan penerimaan pesannya bersifat tatap muka dan setiap jamaah mendapat kesan atau penglihatan antara satu dengan yang lainnya yang cukup dekat sehingga pada saat timbul pertanyaan maupun sesudahnya dapat memberikan tanggapan kepada masing-masing sesuai perorangan.

\section{Daftar Pustaka}

Huda, Nurul. (2010).Pedoman Majelis Taklim.Jakarta: KODI DKI Jakarta. Arifin,H.M. (2005). Kapita Selekta Pendidikan Islam (Islam dan Umum). Jakarta: BumiAksara.

Chulsum dan Novia.(2006).Kamus Besar Bahasa Indonesia. Surabaya: Kashiko.

Dewan Redaksi Ensiklopedia Islam.(2004).Ensiklopedia Islam. Jakarta: Ichtiar Baru Van Haefa.

Mulyana,Deddy.(2005).Ilmu Komunikasi Suatu Pengantar. Bandung: PT.Remaja Rosdakarya.

Nurudin. (2012). Sistem Komunikasi Indonesia. Jakarta: PT. Rajagrafindo Persada. 
Sarwono,Sarlito Wirawan.(2000). Pengantar Ilmu Sosiologi. Jakarta : PT. Bulan Bintang.

Muhsin.(2009). Manajemen Majlis Taklim. Jakarta: Pustaka Intermasa.

Roudhonah. (2007). Ilmu Komunikasi. Jakarta: Jakarta Pers 